\title{
Editorial
}

\section{The year that passed - 2011}

The editorial board for Public Health Nutrition has seen another year pass, with an ever increasing number of submitted papers, larger volumes and an increased number of pages over the year.

\section{Impact factor}

The increased number of pages that we have had over the last few years has now taken its toll: in the latest 'verdict' from ISI Journal Citation Reports (JCR), our impact factor decreased from 2.79 to 2.09 in June this year. This reduction makes us all who put a substantial amount of work into the journal disappointed, wondering what we did wrong. It is good to know that we are not alone - the same drop happened to our big sister journal, British Journal of Nutrition ${ }^{(1)}$, which experienced an impact factor drop from $3 \cdot 45$ to $3 \cdot 07$. These drops are, for both journals, probably due to an increased number of papers being published in the years 2008 and 2009, the years that the 2010 impact factor is based on. Just to remind our readers: the impact factor is based upon the number of citations of papers published in the last two years, divided by the number of papers. For 2008 plus 2009, we published 456 papers, while the corresponding figure for 2007 plus 2008 was only 343 papers. We are now ranked as number 39 out of 70 nutrition journals.

Our 5-year impact factor, which may be more interesting than the 1 -year version, is higher, $2 \cdot 817$, and moves the journal up to number 25 out of the 70 nutrition journals. The Article Influence score that is also published by JCR calculates the relative importance of the journal per paper. When this score is more than 1 , it indicates that the journal has above-average influence. Our journal ranked relatively high here: at $0 \cdot 819$, Public Health
Nutrition was ranked as number 22 out of the 70 listed nutrition journals in JCR.

\section{What renders many citations?}

Table 1 shows papers published in Public Health Nutrition in 2008 and 2009 that were the most highly cited in 2010 (data from ISI Web of Science in October 2011).

Reviews generally get many citations. For our journal, we can see that papers in novel areas such as local community interventions, methodology papers and large cohort studies are also highly cited.

In the broader scope of all scientific journals, papers in research areas that are moving quickly and/or have a clear market value, such as pharmaceutics and molecular biology, get many citations; as do papers in clinical journals. An example of a high-ranking journal is Nature with an impact factor of $36 \cdot 1$ according to JCR. Among journals in paediatrics, the highest ranking is Pediatrics, with an impact factor of $5 \cdot 39$. The highest ranking of the nutrition journals, if we do not count those devoted merely to publishing reviews, is American Journal of Clinical Nutrition, with an impact factor of $6 \cdot 61$.

\section{Health impact factor}

We might be accused of discussing 'sour grapes' here, but again, pointing to our earlier editorial about the nude emperor $^{(12)}$, is it not time to start discussing a 'health impact factor' as a supplement to the above-mentioned impact factor for journals related to human health? It seems evident that papers published in the area of paediatrics as well as in nutrition can have a profound effect on human

Table 1 Public Health Nutrition papers published in 2008 and 2009 that were highly cited in 2010 and their total citations to date

\begin{tabular}{|c|c|c|c|}
\hline & Type of paper & Citations in 2010 & Total citations to date \\
\hline Bodor et al. (2) & Research paper & 23 & 50 \\
\hline Moreno et al. ${ }^{(3)}$ & Research paper & 16 & 44 \\
\hline McLean et al. ${ }^{(4)}$ & Research paper & 14 & 34 \\
\hline Swinburn et al. ${ }^{(5)}$ & Policy paper & 11 & 28 \\
\hline Wen et al. ${ }^{(6)}$ & Research paper & 10 & 19 \\
\hline Zhang et al. ${ }^{(7)}$ & Research paper & 10 & 19 \\
\hline Psaltopoulou et al. ${ }^{(8)}$ & Research paper & 10 & 18 \\
\hline Thompson et al. ${ }^{(9)}$ & Research paper & 9 & 40 \\
\hline Pearson et al. ${ }^{(10)}$ & Review & 9 & 30 \\
\hline Galvez et al. $^{(11)}$ & Research paper & 8 & 21 \\
\hline
\end{tabular}


health, which is not reflected in the journal impact factor or in the currently existing systems for assessing quality of research.

\section{Thank you to all for a good year}

This journal is the result of efforts from administrative as well as editing staff at the Nutrition Society and Cambridge University Press. Additionally, a large number of volunteer scientists devote their time and effort into making the journal interesting and in developing the content in regard to editorial material as well as paper review. And finally, we have a tremendous amount of papers from eager authors submitted every year. The number of papers has steadily increased during the 14 years that the journal has existed. Clearly the journal is generating a lot of interest, and the field of public health nutrition is expanding. Thank you to you all, the readers, authors and 'citers', for another great year - we hope to welcome you back in 2012.

Agneta Yngve
Editor-in-Chief
Marilyn Tseng
Geraldine McNeill
Irja Haapala
Allison Hodge
Deputy Editors

\section{References}

1. Calder PC (2011) More citations, but a fall in impact factor. Br J Nutr 106, 789-792.
2. Bodor JN, Rose D, Farley TA et al. (2008) Neighbourhood fruit and vegetable availability and consumption: the role of small food stores in an urban environment. Public Health Nutr 11, 413-420.

3. Moreno LA, Gonzalez-Gross M, Kersting M et al. (2008) Assessing, understanding and modifying nutritional status, eating habits and physical activity in European adolescents: the HELENA (Healthy Lifestyle in Europe by Nutrition in Adolescence) Study. Public Health Nutr 11, 288-299.

4. McLean E, Cogswell M, Egli I et al. (2009) Worldwide prevalence of anaemia, WHO Vitamin and Mineral Nutrition Information System, 1993-2005. Public Health Nutr 12, 444-454.

5. Swinburn B, Sacks G, Lobstein T et al. (2008) The 'Sydney Principles' for reducing the commercial promotion of foods and beverages to children. Public Health Nutr 11, 881-886.

6. Wen CP, David Cheng TY, Tsai SP et al. (2009) Are Asians at greater mortality risks for being overweight than Caucasians? Redefining obesity for Asians. Public Health Nutr 12, 497-506.

7. Zhang XH, Woo J \& Heller RF (2009) Increasing dietary fish intake has contributed to decreasing mortality from CHD among the older population in Hong Kong. Public Health Nutr 12, 1248-1253.

8. Psaltopoulou T, Kyrozis A, Stathopoulos P et al. (2008) Diet, physical activity and cognitive impairment among elders: the EPIC-Greece cohort (European Prospective Investigation into Cancer and Nutrition). Public Health Nutr 11, 1054-1062.

9. Thompson FE, Kipnis V, Midthune D et al. (2008) Performance of a food-frequency questionnaire in the US NIH-AARP (National Institutes of Health-American Association of Retired Persons) Diet and Health Study. Public Health Nutr 11, 183-195.

10. Pearson N, Biddle SJ \& Gorely T (2009) Family correlates of fruit and vegetable consumption in children and adolescents: a systematic review. Public Health Nutr 12, 267-283.

11. Galvez MP, Morland K, Raines C et al. (2008) Race and food store availability in an inner-city neighbourhood. Public Health Nutr 11, 624-631.

12. Yngve A, Tseng M, McNeill G et al. (2011) Is the emperor nude? Impact factor or health impact factor? Public Health Nutr 14, 753. 